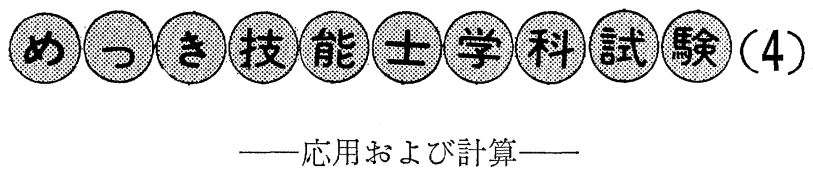

The Theory Test in the Qualifying Examination for the Plating Technicians (Part IV) -Application and Calculation-

めっき技能士検定を受ける人への実際の手 引きとなるよう, 過去に学科試験に出題され た試験問題をとりあげ，電気めっき関係の応 用，計算などの問題を中心に考える。

\section{5. 濃度の計算}

[問]

問1. $\mathrm{pH} 1.0$ 塩酸を100倍に薄めると $\mathrm{pH}$ 約3.0亿なる。

問2. $\mathrm{pH} 3.5$ の標準溶液を純水で 2 倍に薄め たら pH が4.5になった。

問3. $\mathrm{pH} 7.0$ の標準溶液を純水で 2 倍に薄め たら，pH6.0亿なった。

問4. 温度 $18^{\circ} \mathrm{C}$, 濃度 $1 / 10 \mathrm{~N}$ (規定) 飞执いて 硫酸は電離度 $58 \%$ であるから強酸であり，

リン酸は電離度 $26 \%$ になるので弱酸であ る。

問5. 工業用濃塩酸（34\%，比重1.17）をう すめて $10 \%$ 希塩酸を作りたい。容量比で濃 塩酸と水とどんな割合にすればよいか。

問6. $1000 l$ のニッケルめっ孚液に $\mathrm{pH}$ 調整 のために濃塩酸を50cc加光た。これは $\mathrm{NiCl}_{2}$ 。
山 崎 龍 一*

Ryuichi Yamazaki
$6 \mathrm{H}_{2} \mathrm{O}$ をいくら加えたことに相当するか。た

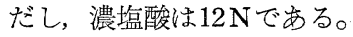

\section{[解説]}

問 1 〜問 5 までは，pH と濃度に関係した 問題です。 $\mathrm{pH}$ 蛒よび電離度に関する説明は 現パー65-9の26ページにありますのでそれを 参照していただくとして簡単沉説明して和き ましょう。

$\mathrm{pH}$ の定義には物理化学的な意味をすった， 水素イオン濃度なたは水素イオン活量による 定義と，J I S Z 8802で定められた標準液 との $\mathrm{pH}$ の差を起電力の差として定義したも のとがありますが，通常めっきや排水処理な どに使用する範囲では泀とんどその結果には 差がありません。

水素イオン濃度または水素イオン活量から の定義は，次のようにされています。

$$
\mathrm{pH}=-\log \mathrm{f} \cdot \mathrm{C}_{\mathrm{H}^{+}}=-\log \mathrm{aH}^{+}
$$

ここで $\mathrm{f}$ は活量係数, $\mathrm{C}_{\mathrm{H}^{+}}{ }^{+}$は水素イオン

* Industrial Research Institute of Kanagawa Prefecture

3173, Showa-machi, Kanazawa-ku, Yokohama-shi, Kanagawa 236 
濃度, $\mathrm{aH}^{+}$は水素イオン活量と呼んでいま 于े

一般に強電解質で，厳密に市つかわない場 合には, 活量係数を 1 として, $\mathrm{pH}=-\log \mathrm{C}_{\mathrm{H}}{ }^{+}$ すなわら，一般に書かれている $\mathrm{pH}=-\log$ $\left[\mathrm{H}^{+}\right]$で用いています。

水素イオン濃度 $\left[\mathrm{H}^{+}\right]$は $1,000 \mathrm{ml}$ 中のグ ラムイオン数で表わされます。

$\mathrm{pH}$ 注，水素イオン濃度の大小表わす符 号で，水素イホン指数とも呼ばれています。 水溶液中に蝚いては, 水分子は一部解離して $\mathrm{H}^{+}$と $\mathrm{OH}^{-}$になっていすすが，中性の水溶 液では $\mathrm{H}^{+}$と $\mathrm{OH}^{-}$とが同量ずつ存在して和 り,酸性では $\mathrm{H}^{+}$が多く,アルカリ性では $\mathrm{OH}^{-}$ が多く存在しています。

水は電離説によって $\mathrm{H}^{+}$と $\mathrm{OH}^{-}$に電離し て捛り，質量作用の法則によると次の式が成 立します。

$$
\frac{\left[\mathrm{H}^{+}\right]\left[\mathrm{OH}^{-}\right]}{\left[\mathrm{H}_{2} \mathrm{O}\right]}=\mathrm{k}
$$

この場合, $\mathrm{H}^{+}$と $\mathrm{OH}^{-}$とに電離する割合 は極めて少なく，それに対し電離していない

表 $2 \mathrm{pH}$ 值; 規定度および濃度

\begin{tabular}{|c|c|c|c|c|}
\hline $\mathrm{pH}$ 值 & \multicolumn{2}{|c|}{ 規定度 $(\mathrm{N})$} & 度 & $(\%)$ \\
\hline & & & $\mathrm{H}_{2} \mathrm{SO}_{4}$ & $\mathrm{HCl}$ \\
\hline 0 & & 1.0 & 4.95 & 3.64 \\
\hline 1 & & 0.1 & 0.495 & 0.364 \\
\hline 2 & $\begin{array}{l}\text { 酸 } \\
\text { の }\end{array}$ & 0.01 & 0.0495 & 0.0364 \\
\hline 3 & 規 & 0.001 & 0.00495 & 0.00364 \\
\hline 4 & 定 & 0.0001 & 0.000495 & 0.000364 \\
\hline 5 & & 0.00001 & 0.0000495 & 0.0000364 \\
\hline 6 & & 0.000001 & 0.00000495 & 0.00000364 \\
\hline 7 & & 性 & & \\
\hline 8 & & 0.000001 & $\mathrm{NaOH} 0.000004 \%$ & \\
\hline 9 & 塩 & 0.00001 & 0.00004 & \\
\hline 10 & 基 & 0.0001 & 0.0004 & \\
\hline 11 & 規 & 0.001 & 0.004 & \\
\hline 12 & 定 & 0.01 & 0.04 & \\
\hline 13 & 度 & 0.1 & 0.4 & \\
\hline 14 & & 1.0 & 4.0 & \\
\hline
\end{tabular}

めっき実務読本より
$\mathrm{H}_{2} \mathrm{O}$ は多量に存在するので, 一定の条件下で は $\mathrm{H}_{2} \mathrm{O}$ 壱一定とみなして、次の式のように なります。

$$
\left[\mathrm{H}^{+}\right]\left[\mathrm{OH}^{-}\right]=\mathrm{k}
$$

この $\mathrm{k}$ の值は常温に物いて $1 \times 10^{-14}$ をと り要与。

純粋の水は中性で, $\left[\mathrm{H}^{+}\right] と\left[\mathrm{OH}^{-}\right]$が等し $<,\left[\mathrm{H}^{+}\right]=1 \times 10^{-7}$, 同じ< $\left[\mathrm{OH}^{-}\right]=1 \times 10^{-7}$ です。

$$
\text { ここで, } \mathrm{pH}=-\log \left[\mathrm{H}^{+}\right]=\log \frac{1}{\left[\mathrm{H}^{+}\right]},
$$

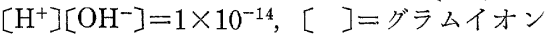
$l l$, の関係をよく覚えて蛙いて下さい。

水素イオン濃度が 0.1 すなわら $10^{-1}$ の液は

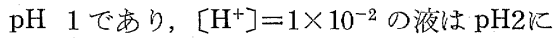
なります。 $\mathrm{pH}$ が 1 違らといらことは水素イ オン濃度で10倍違らといらことです。

表 2 にH と濃度の関係を揭げて扣きま के。

水素イオン濃度を $\mathrm{pH}$ にな挌したり， $\mathrm{pH}$ を水素イオン濃度にな扎したりすることは, 排水処理などでよく行なわ机をす。最近は函 数電卓が普及して和りますか ら対数計算のできる計算機な ら簡単飞計算できますが，刘 数表を使用する計算例をあげ て扣きましょら。

水素イオン濃度を $\mathrm{pH}$ にな 和すには，次のようにしま 于。

例えば， $\left[\mathrm{H}^{+}\right]=3.5 \times 10^{-3}$ のときの $\mathrm{pH}$ は $\log \left[\mathrm{H}^{+}\right]=$ $\log \left(3.5 \times 10^{-3}\right)=\log 3.5-3$, $\log 3.5$ を対数表でひくと 0.544 ですから， $0.544-3=$ $-2.456, \mathrm{p} \mathrm{H}=-\log \left[\mathrm{H}^{+}\right]$で すからーをつけて, $\mathrm{pH}$ は 2 . 546となります。

逆に pH3.5 の溶液の水素 インン濃度は幾つになるでし 
25。

$\log \left[\mathrm{H}^{+}\right]=-3.5$ ですから, $\log \left[\mathrm{H}^{+}\right]=0.5$ $-4,-4$ は $\log 10^{-4}$ で，0.5孛対数表で逆に ひくと，3.162ですから $\left[\mathrm{H}^{+}\right]=3.162 \times 10^{-4}$ となりなす。

余談になりますが，これらの計算は排水処

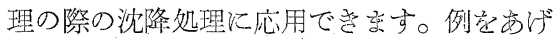
て計算してみ京すが興味のない人はとばして

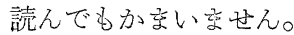

水に難溶性の塩 $\mathrm{AB}$ が $\mathrm{A}^{+}$と $\mathrm{B}^{-}$飞霓離 する場合の平衡は，質量作用の法則から $\left[\mathrm{A}^{+}\right]$ $\left[\mathrm{B}^{-}\right]=\mathrm{k}$ とすることができ，このときの $\mathrm{k}$

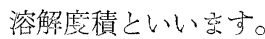

例光ば， $\mathrm{Fe}^{2+}$ を中和沈降処理で $\mathrm{Fe}^{2+}$ 老 1 ppm以下にしたいが，そのと党の $\mathrm{pH}$ はどの 位にすればよいか，というようなと总，

$\mathrm{Fe}^{2+}+2 \mathrm{OH}^{-}=\mathrm{Fe}(\mathrm{OH})_{2}$ の反応を用い, $\mathrm{Fe}$ $(\mathrm{OH})_{2}$ の溶解積と $\mathrm{pH}$ の関係を用いれば簡 単に求めることがで亲す。

鉄 $1 \mathrm{ppm}$ というのは $1 l$ 中に $1 \times 10^{-3} \mathrm{~g}$ の 鉄が存在しているわけですから，グラムイオ ン濃度 $\left[\mathrm{Fe}^{2+}\right]$ 亿するには，濃度を原子量で割 ってやり弃す。 $\left[\mathrm{Fe}^{2+}\right]=1 \times 10^{-3} / 55.8=1.79$ $\times 10^{-5}$ ，守なわ鉄 $1 \mathrm{ppm}$ は $1.79 \times 10^{-5}$ グ ラムイオン $/ l$ です。 $\mathrm{Fe}(\mathrm{OH})_{2}$ の溶解度積は $1.8 \times 10^{-15}$ 位とされて物り，この值を使うと と $\left[\mathrm{Fe}^{2+}\right]\left[\mathrm{OH}^{-}\right]^{2}=1.8 \times 10^{-15}$ なりますから，

$$
\left[\mathrm{Fe}^{2+}\right]=\frac{1.8 \times 10^{-15}}{\left[\mathrm{OH}^{-}\right]^{2}}=1.79 \times 10^{-5}
$$

を計算すればよいわけです。すると

$$
\left[\mathrm{OH}^{-}\right]=\left(\frac{1.8 \times 10^{-15}}{1.79 \times 10^{-5}}\right)^{\frac{1}{2}} \doteqdot 1 \times 10^{-5}
$$

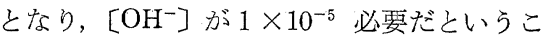

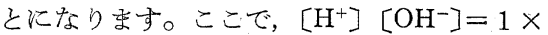
$10^{-14}$ といら関係がありますから

$$
\begin{aligned}
& {\left[\mathrm{H}^{+}\right]=1 \times 10^{-14} /[\mathrm{OH}]=1 \times 10^{-14} /} \\
& 1 \times 10^{-5}=1 \times 10^{-9} \\
& \mathrm{pH}=-\log \left[\mathrm{H}^{+}\right]=-\log \left[1 \times 10^{-9}\right]=9 \text { で }
\end{aligned}
$$

pH9 以上にすれば, 残留鉄イオンは $1 \mathrm{ppm}$ に
なるはずです。

さて, 問題にもどりましょら。問 1 は $\mathrm{pH} 1$

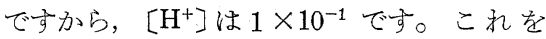
100倍にうすめるわけですから， $1 \times 10^{-1} / 100$ $=1 \times 10^{-3}$ で $\mathrm{pH}$ は 3 となります。 $\mathrm{pH}$ 異なると濃度では10倍異なるということです 标。

問 2 は $\mathrm{pH} 3.5$ と $\mathrm{pH} 4.5$ ですから $\mathrm{pH}$ で 1 違います。ですから問 1 と同じように考光れ ば，2倍でなく10倍にしな汀ればならないは すです。では 2 倍に薄めたらいくつになるで しょら。pH3.5 は $\left[\mathrm{H}^{+}\right]=3.162 \times 10^{-4}$ で, これを 2 で割った濃度ですから $\left[\mathrm{H}^{+}\right]=1.581$ $\times 10^{-4}$ で，これを $\mathrm{pH}$ にな物すと $\mathrm{pH} 3.8$ 亿 なり李す。

問 3 はなんでもない問題ですが，ときどき ひっかかる人がいます。問2のように計算す ると $\mathrm{pH} 7.3$ になり，数值が違うので䛊りだ といらことはすぐわかりますが，このように 解いた人は，問題が $\mathrm{pH} 7$ の溶液を純水で10 倍にうすめると $\mathrm{pH} 8$ になる，となっている と密がってしまいます。

純水の $\mathrm{pH}$ は $7.0 て ゙\left[\mathrm{H}^{+}\right]=1 \times 10^{-7},\left[\mathrm{OH}^{-}\right]$ $=1 \times 10^{-7}$ と同じ濃度の $\left[\mathrm{H}^{+}\right]$と[ $\left.\mathrm{OH}^{-}\right]$を含 んで敊り, pH 7.0 の標準溶液もまた $\left[\mathrm{H}^{+}\right]=$ $1 \times 10^{-7}$ ですから $\left[\mathrm{OH}^{-}\right]$も $1 \times 10^{-7}$ のはず です。同じ濃度のものをいくら加えても希釈 にはならないわ沈で $\mathrm{pH}$ は変りません。

では次に，pH 5 の溶液を純水で 1000 倍に うすめたらどうなるでしょうか。また $\mathrm{pH} 5$ の溶液と $\mathrm{pH} 6$ の同じ溶液を 1 対 1 で混ばた らどうなるでしょう。 $\mathrm{pH} 5$ の溶液の水素イ オン濃度は $1 \times 10^{-5}$ です。これを1000倍にう すめると $1 \times 10^{-8}$ になります。 $\mathrm{pH}$ は 8 とい らことになりをすが，これは少し変でする。 この方法でいくと酸を薄めてアルカリを作る ことができるといらことになってしまいま す。いままでの計算にどこか間違いがあった 
のでしょらか。

穾㤁，い末までの計算は簡便法で，全く正 しいといら方法ではないのです。いまの問題 は，こらなりをす。 pH 5 の溶液を 1000 倍に 薄めるということは， pH 5 の溶液に対して 純水 999 を加えてやることです。このとき， 純水とい党ども $\left[\mathrm{H}^{+}\right]=1 \times 10^{-7}$ であるはず です。従って，次のように計算しなければな らないのです。

$$
\begin{array}{r}
{\left[\mathrm{H}^{+}\right]=\frac{\left(1 \times 10^{-5}\right) \times 1+\left(1 \times 10^{-7}\right) \times 999}{1000}} \\
=1.099 \times 10^{-7}
\end{array}
$$

で $\mathrm{pH}=-\log \left(1.099 \times 10^{-7}\right)=6.96$

ただ，基準になる $\mathrm{pH}$ と水の $\mathrm{pH} 7$ との 濃度差以内の希釉倍率の場合には，ほとんど 䛊差が問題にならなかったので簡便法で計算 してよかったのです。

\begin{tabular}{|c|c|c|}
\hline 酸 & $\mathrm{HCl}$ & 0.92 \\
\hline 硝 & $\mathrm{HNO}_{3}$ & 0.92 \\
\hline 硫 & $\mathrm{H}_{2} \mathrm{SO}_{4}$ & 0.61 \\
\hline ン 酸 & $\mathrm{H}_{3} \mathrm{PO}_{4}$ & 0.27 \\
\hline フ ッ化 水素 & $\mathrm{H}_{2} \mathrm{~F}_{2}$ & 0.13 \\
\hline 酢 & $\mathrm{CH}_{3} \mathrm{COOH}$ & 0.013 \\
\hline ホ ウ 酸 & $\mathrm{H}_{3} \mathrm{BO}_{3}$ & 0.0001 \\
\hline 苛＼cjkstart性力 リ & $\mathrm{KOH}$ & 0.91 \\
\hline 苛性ソーダー & $\mathrm{NaOH}$ & 0.91 \\
\hline 水酸化バリウム & $\mathrm{Ba}(\mathrm{OH})_{2}$ & 0.77 \\
\hline アン亡 & $\mathrm{NH}_{4} \mathrm{OH}$ & 0.013 \\
\hline 塭 化 カ リ & $\mathrm{KCl}$ & 0.85 \\
\hline 塩化ナトリウム & $\mathrm{NaCl}$ & 0.84 \\
\hline 塩化アンモニウム & $\mathrm{NH}_{4} \mathrm{Cl}$ & 0.84 \\
\hline 酢 酸 力 リ & $\mathrm{CH}_{3} \mathrm{COOK}$ & 0.88 \\
\hline 酢 酸ソーダー & $\mathrm{CH}_{3} \mathrm{COONa}$ & 0.79 \\
\hline 硫 酸ソーダ一 & $\mathrm{Na}_{2} \mathrm{SO}_{4}$ & 0.70 \\
\hline 硫 酸 力 1) & $\mathrm{K}_{2} \mathrm{SO}_{4}$ & 0.72 \\
\hline 塩化バリウム & $\mathrm{BaCl}_{2}$ & 0.77 \\
\hline 塩 化 亚 鉛 & $\mathrm{ZnCl}_{2}$ & 0.73 \\
\hline 硫 酸 垔 鉛 & $\mathrm{ZnSO}_{4}$ & 0.40 \\
\hline 硫＼cjkstart酸 & $\mathrm{CuSO}_{4}$ & 0.39 \\
\hline
\end{tabular}

表 3 酸,アルカリ, 塩類の電離度 $(0.1 \mathrm{~N})$
この理由がわかれば，pH 5 と pH6の同じ 水溶液の混合も簡単です。 $1: 1$ で流

$$
\begin{aligned}
{\left[\mathrm{H}^{+}\right]=\frac{\left(1 \times 10^{-5}\right) \times 1+\left(1 \times 10^{-6}\right) \times 1}{2} } & \\
= & 5.5 \times 10^{-6} .
\end{aligned}
$$$$
\mathrm{pH}=-\log \left(5.5 \times 10^{-6}\right)=5.26 \text {, }
$$

$1: 3$ の混合なら

$$
\begin{gathered}
{\left[\mathrm{H}^{+}\right]=\frac{\left(1 \times 10^{-5}\right) \times 1+\left(1 \times 10^{-6}\right) \times 3}{4}} \\
\mathrm{qH}=-\log \left(3.26 \times 10^{-6}\right)=5.49
\end{gathered}
$$

となります。

繰り返しますが，純水で希釈する場合，濃 度差倍率以上の希䣋倍率のと㐘には注意して 下さい。その場合，無限に $\mathrm{pH} 7$ に近くなる はずです。

問 4 は電離度に関係した問題です。

$\mathrm{NaCl}$ などを水に溶かすと, $\mathrm{Na}^{+}$の陽イオ ンと $\mathrm{Cl}^{-}$の䧔イオン学生じます。電解質が溶 液中で陽イオン（カチオン）と陰イオン（ア ニオン）を生ずることを電離するといいま 于े。

溶液中で雵離する場合, 電解質の全部がイ オンになるものばかりではなく，分子のまま 溶けている部分とイオンになっている部分と にわかれることがあります。この電離の度合 は，電解質の種類や条件によって変ります が，溶液中で電解質の何割位が電離している かを示すのが電離度で，95\%が電離していれ ば霄離度 0.95 です。参考までに酸，アルカ リ，塩類の電離度の例を表 3 K示しなす。

電離度の大きなものを強電解質, 小さいも のを弱電解質と呼んでいますが，一般に電離 度が 0.5 以上のものを強電解質, 酸の場合に は強酸，それ以下のものを弱電解質，酸の場 合には弱酸と呼えでいます。

従って，問 4 の硫酸は50\%以上の電離度な ので強酸，リン酸50\%は以下なので弱酸に分 類されます。

問 5 は, 比重と濃度の問題です。

比重については前回説明しました。34\%で 
比重 1.17 の濃塩酸とはどんな状態でしょう か。例えば，容量で $1 l$ とったとすると比重 が，1.17ですから，この塩酸の重量は $1.17 \mathrm{~kg}$ 每るはずです。一般に\%は重量パーセントで 表わされていますから，34\%が塩酸といらこ とは $397.8 \mathrm{~g}$ が塩酸であるといらことです。 これをらすめて $10 \%$ 塩酸にするわけです。

いま $1 l$ で計算してみますと，加兄る水の 量を妨をする，

$$
\frac{397.8}{1170+\mathrm{x}} \times 100=10
$$

になればよいはずです。 Xは $2808 \mathrm{~g}$ ，すなわ ち $2,808 l$ 必要となるわけで, 塩酸 1 亿対し て水 2,808 の容量が必要です。この薄められ た10\%塩酸の比重は，重さを体積で割ればよ いわけですから, 重さは $1170 \mathrm{~g}+2808 \mathrm{~g}=$ $3978 \mathrm{~g}$ で，体積は $1000 \mathrm{cc}+2808 \mathrm{cc}=3808 \mathrm{cc}$ で すから，3978/3808=1,045となります。

問 6 亿は規定度 $(\mathrm{N})$ がでてきます。

規定度は濃度を表わす単位の一つですが， 化学反応関する濃度を表わします。規定度 は, 溶液 $1 l$ 中に含まれている溶質のグラム 当量数であらわしをす。グラム当量とは原子 量または分子量をその価数で割った「当量」 をグラムで表わしたものです。例館ば，硫酸 $\mathrm{H}_{2} \mathrm{SO}_{4}$ は分子量 98 で, 酸としては 2 価で作用

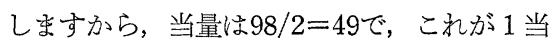
量です。そして，これにグラムをつけた $49 \mathrm{~g}$ が硫酸の 1 グラム当量ということになりま す。そして, $1 l$ の溶液中に $\mathrm{H}_{2} \mathrm{SO}_{4}$ として49 $\mathrm{g}$ ，すなわち 1 グラム当量含京れている場 合, この硫酸溶液は 1 規定, または 1 ノルマ ル（N）の溶液であるといいます。

これと似たものに，モル濃度といらのがあ りますが，これは $1 l$ 中に含まれるグラム分 子数を表わし委す。硫酸の例でいい亦すと， 1 グラム分子は $98 \mathrm{~g}$ です。ですから $1 l$ 中に $\mathrm{H}_{2} \mathrm{SO}_{4}$ として, $98 \mathrm{~g}$ 含んでいる硫酸溶液は 1 モル溶液と呼び, これは 2 規定の溶液とい らことになります。
塩酸の場合は分子量 36.5 がですから, $\mathrm{HCl}$ として $1 l$ 中に $36.5 \mathrm{~g}$ 含京れていると 1 モル 溶液で，塩酸は酸として1価で働きなすか ら， 1 グラム当量は $36.5 \mathrm{~g} て ゙ ， 1$ モル溶液は 1 規定といらわけです。

そこで12N（ノルマル・規定）の塩酸とい らのは, 1 中 中に $36.5 \mathrm{~g} \times 12=438 \mathrm{~g}$ のCl を 含んで和り， $\mathrm{Cl}$ としては $423 \mathrm{~g}$ 含有している ということになります。これを50cc加光たわ けですから， $\mathrm{HCl}$ 又はCl 換算しますと

$$
\begin{aligned}
\mathrm{HCl} & =\frac{438 \mathrm{~g}}{1,000} \times 50=21.9 \mathrm{~g} \\
\mathrm{Cl} & =\frac{426 \mathrm{~g}}{1,000} \times 50=21.3 \mathrm{~g}
\end{aligned}
$$

になります。これが何グラムの $\mathrm{NiCl}_{2} \cdot 6 \mathrm{H}_{2} \mathrm{O}$ に相当するかといらのが問題です。

$\mathrm{NiCl}_{2} \cdot 6 \mathrm{H}_{2} \mathrm{O}$ の分子量を計算してみます と, $58.7(\mathrm{Ni})+35.5(\mathrm{Cl}) \times 2+18\left(\mathrm{H}_{2} \mathrm{O}\right) \times 6$ =237.7飞なります。 $\mathrm{NiCl}_{2} \cdot 6 \mathrm{H}_{2} \mathrm{O}$ は $\mathrm{Cl}$ が 2 つで構成されていますから，35.5(Cl)×2が 237.7 対応します。従って, $\mathrm{Cl}$ を基準にと れば71：237.7， $\mathrm{HCl}$ を基準にすれば $73 ：$ 237.7の比率になります。いま, 加えた $\mathrm{HCl}$ は21.9g ですから, $73: 237.7=21.9: x$, または $\mathrm{Cl}$ から計算すれば $71: 237.7=21.3$ : $\mathrm{x}$ という比例計算をすれば答は求められま す。 $\mathrm{x}$ は71.3, すなわち, $12 \mathrm{~N}$ 塩酸 $50 \mathrm{cc} の$ 塩素は, $\mathrm{NiCl}_{2} \cdot 6 \mathrm{H}_{2} \mathrm{O}$ として71.3 $\mathrm{g}$ の塩素と 等しいということになり京す。

この問の場合, 濃度を求められているので はなく, 量を求められているのですから, $1000 l$ のといら量には関係岁りせん。ただ この問題の場合, 各原子量を書いて标いてく れると親切なのですが。

では, 次の問題を○かメで答えて下さい。 1) $30 \% の \mathrm{H}_{2} \mathrm{SO}_{4}$ 溶液 $10 \mathrm{~kg}$ を水 $10 \mathrm{~kg}$ で薄め れば, $15 \%$ の $\mathrm{H}_{2} \mathrm{SO}_{4}$ 溶液になる。

2) $30 \%$ の $\mathrm{NaOH}$ 溶液 $100 l$ 水で $300 l$ 飞 薄めたら，10\%の $\mathrm{NaOH}$ 溶液になった。

(以下次号) 